\title{
Use of mollusks in zoohandicraft manufacturing in the Amazon Region
}

\section{Mara Rúbia Ferreira Barros ${ }^{1}$ and Rafael Anaisce das Chagas ${ }^{2}$,*}

${ }^{1}$ Universidade Federal Rural da Amazônia. Programa de Pós-Graduação em Aquicultura e Recursos Aquáticos Tropicais. Estrada Principal da UFRA, 2501. Montese. Belém-PA, Brazil (CEP 66077-530).

${ }^{2}$ Universidade Federal Rural da Amazônia. Laboratório de Ecologia Bentônica Tropical. Avenida Perimetral, S/No. Terra Firme. Belém-PA, Brazil (CEP 66077830). Email: rafaelanaisce@hotmail.com.

\begin{abstract}
The use of mollusks by riverine and coastal families occurs mainly through the sale to add extra income to the family. However, little knowledge about the species that are marketed in the confection of zoohandicraft. From the above, the present study aims to characterize the diversity of mollusks used in zoohandicraft of the State of Pará, Brazil. To carry out this study, between March and August 2014, traditional handicraft marketing points were visited in the Municipality of Belém, the state capital. In all, 16 species of mollusks were found, $56 \%$ of gastropods and $44 \%$ of bivalves, arranged in five types of zoohandicraft (bio-jewels, ornaments for the ceiling, souvenirs, keychains, and certificate holders), and shells. Among the most abundant species, we highlight the bivalves Anomalocardia flexuosa (Linnaeus, 1767) and Triplodon corrugatus (Lamarck, 1819), it is emphasized that no species is on the red list of species threatened with extinction. It is concluded that the few existing data on the production and trade of zoohandicraft are insufficient to measure anthropogenic effects on the mollusks used to make the materials.
\end{abstract}

Keywords: Gastropods; Bivalves; Anomalocardia flexuosa; Triplodon corrugatus.

\section{Introduction}

It is defined as zoohandicraft any form of handicraft that used animals or parts of these in its confection (Farias and Rocha-Barreira, 2007). This activity is characterized as a form of artistic and cultural expression, of family and hereditary character, framed in
Received

February 22, 2019

Accepted

March 23, 2019

Released April 30, 2019

Full Text Article

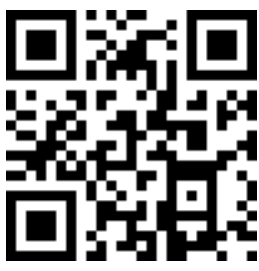

\section{ORCID}

(1) 0000-0003-1354-7550 Mara Rúbia Ferreira Barros

(ㄱ) 0000-0002-1555-6154

Rafael Anaisce das Chagas 
Studies on mollusks are generally directed to the population, fisheries and cultivation aspects and/or as fauna associated with other organisms (Chagas and Herrmann, 2015, 2016; Chagas et al., 2018a, b). However, Alves et al. (2006) scientific assessments that focus on the production, trade, or diversity of organisms used in zoohandicraft are incipient or meager. In addition, the effects of anthropogenic pressure on the species used are not known (Jesus et al., 2017).

The study by Silva et al. (2007) points out that with the increasing demand for tourism, the demand for handmade products with the use of animals has gradually increased, leading to a greater exploitation of species for the manufacture of handicrafts.

In this sense, the present study aims to characterize the diversity of mollusks used in zoohandicraft of the State of Pará, Eastern Amazonia.

\section{Material and methods}

This study was carried out in the State of Pará, Eastern Amazonia, between March and August 2014. The places where the handicrafts were sold in the city were Commercial Center, the Ver-OPeso Market, and Praça da República. These sites were chosen due to the great flow of tourists that circulate in these places.

In each site visited, the zoohandicraft found was photographed so that later the taxonomic identifications of the molluscs could be made. For the identification of the molluscs, specialized literature was used, such as Matthews-Cascon and Barreira (2006) and Rios (2009).

\section{Results and discussion}

In total, 16 species of mollusks were found, 56\% (9 spp.) gastropods and $44 \%$ (7 spp.) bivalves, arranged in five types of zoohandicraft (Table 1). The variety of products in which mollusks gastropods and bivalves are used in their composition, among the materials were found bio-jewels, ornaments for the ceiling, souvenirs, keyrings, and banknote holder, being some organisms were sold without any ornamentation, namely only the shell (Figure 1, 2 and 3).

The most abundant species of the

Amazonian zoohandicraft are the bivalves Anomalocardia flexuosa (Linnaeus, 1767) and Triplodon corrugatus (Lamarck, 1819), native mollusks of marine and limnic environments, respectively. Such mollusks were found in a variety of materials (Table 1).

For the confection of Amazonian zoohandicraft, in addition to mollusks or parts, additional materials such as wood, metal alloys, glue, epoxy, varnish, paint of various colors, seeds, nylon wire, among others, among others, are also used.

Traders say that they do not know the origin of the organisms and that they are generally bought by "informal merchants" - people who sell their products on the street. Another important information to note is that none of the species found are in the red list of species threatened with extinction from the Ministry of the Environment of Brazil - MMA (Subirá et al., 2018), based on data from the International Union for Conservation of Nature (IUCN).

In previous studies on biodiversity used in zoohandicraft practiced in the Brazilian Northeast, Alves et al. (2006) found that mollusks represent $99.6 \%$ (24 spp.) of the species used in zoohandicraft commercialized in the Municipality of Recife, Pernambuco State, and Silva et al. (2007), found a representativity of mollusks of $\sim 89 \%$ (71 spp.) in the State of Paraíba. Even with a higher number of mollusk species found by Alves et al. (2006) e Silva et al. (2007), in comparison to the results of this study, we highlight the greater diversity of gastropods in the zoohandicraft confection. 
Table 1. Mollusks used in the confection of the zoohandicraft in the Amazon region. Legend: code referring to species in respective Figures 1,2 and $3(\mathbf{N})$, exemplifying the types of products marketed.

\begin{tabular}{|c|c|c|c|c|c|c|c|}
\hline Taxa/Family & Specie & $\mathbf{N}$ & 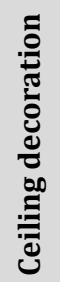 & 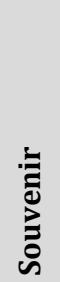 & 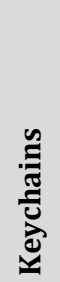 & $\begin{array}{l}\frac{n}{d} \\
\frac{0}{0} \\
\frac{0}{1} \\
\frac{0}{0}\end{array}$ & 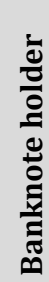 \\
\hline \multicolumn{8}{|l|}{ Gastropoda } \\
\hline Melongenidae & Pugilina morio (Linnaeus, 1758) & 1 & & & & & \\
\hline Neritidae & Nerita fulgurans Gmelin, 1791 & 4 & & & & & \\
\hline Ampullaridae & Pomacea nais Pain, 1949 & 5 & & & & & \\
\hline Strophocheilidae & Megalobulimus leonardosi & 6 & & & & & \\
\hline Muricidae & Stramonita brasiliensis Claremont \& Reid, 2011 & 7 & & & & & \\
\hline Olividae & Olivella sp. & 8 & & & & & \\
\hline Strombidae & Lobatus raninus (Gmelin, 1791) & 9 & & & & & \\
\hline Cypraeidae & Naria acicularis (Gmelin, 1791) & 10 & & & & & \\
\hline Nassaridae & Nassarius conoidalis (Deshayes, 1832) & 16 & & & & & \\
\hline \multicolumn{8}{|l|}{ Bivalvia } \\
\hline Ostreidae & Crassostrea tulipa (Lamarck, 1819) & 3 & & & & & \\
\hline \multirow{3}{*}{ Veneridae } & Anomalocardia flexuosa (Linnaeus, 1767) & 2 & & & & & \\
\hline & Leukoma pectorina (Lamarck, 1818) & 14 & & & & & \\
\hline & Tivela mactroides (Born, 1778) & 15 & & & & & \\
\hline Mytilidae & Mytella guyanensis (Lamarck, 1819) & 11 & & & & & \\
\hline Hyriidae & Triplodon corrugatus (Lamarck, 1819) & 12 & & & & & \\
\hline Cardiidae & Dallocardia manueli (Prado, 1993) & 13 & & & & & \\
\hline
\end{tabular}

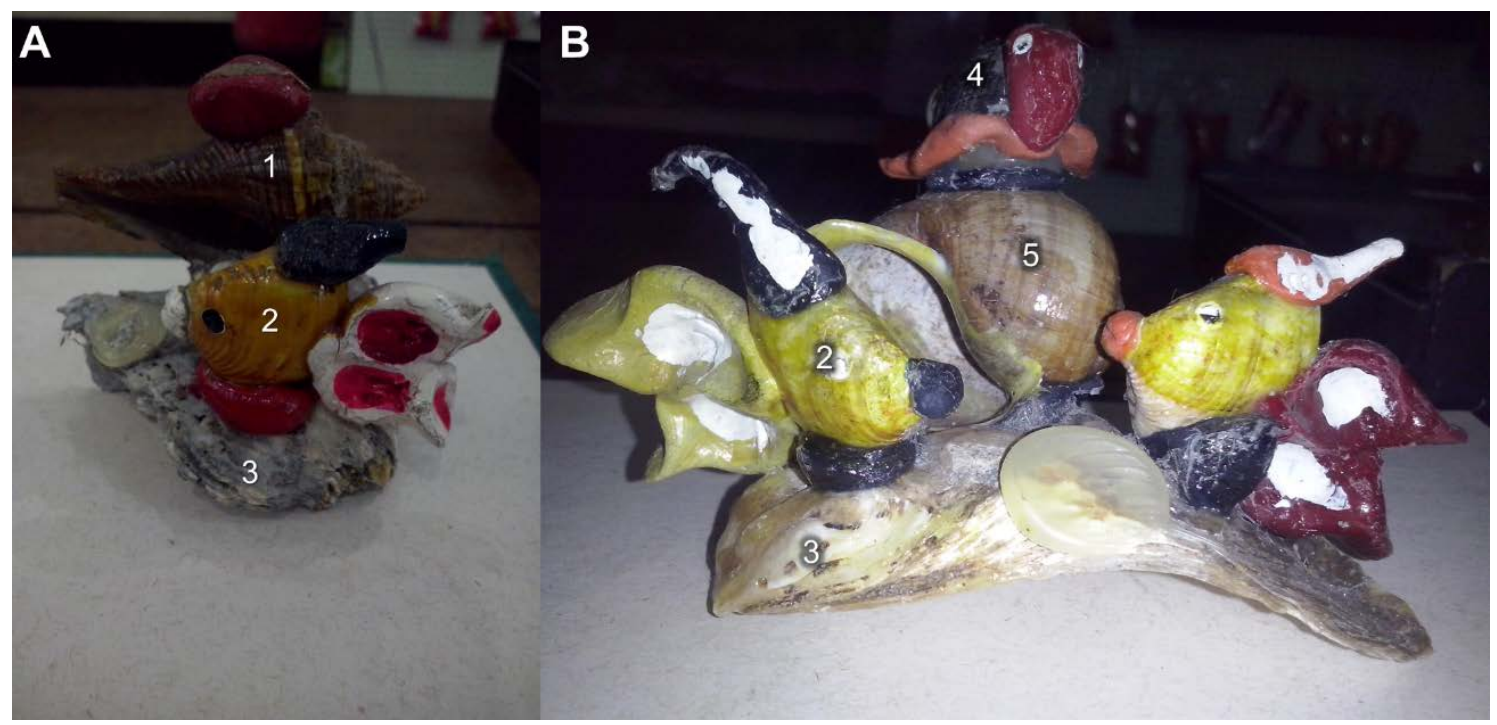

Figure 1. A and B are an example of zoohandicraft marketed in the Amazon Region. Species used: Pugilina morio (1), Anomalocardia flexuosa (2), Crassostrea tulipa (3), Nerita fulgurans (4), and Pomacea nais (5). 


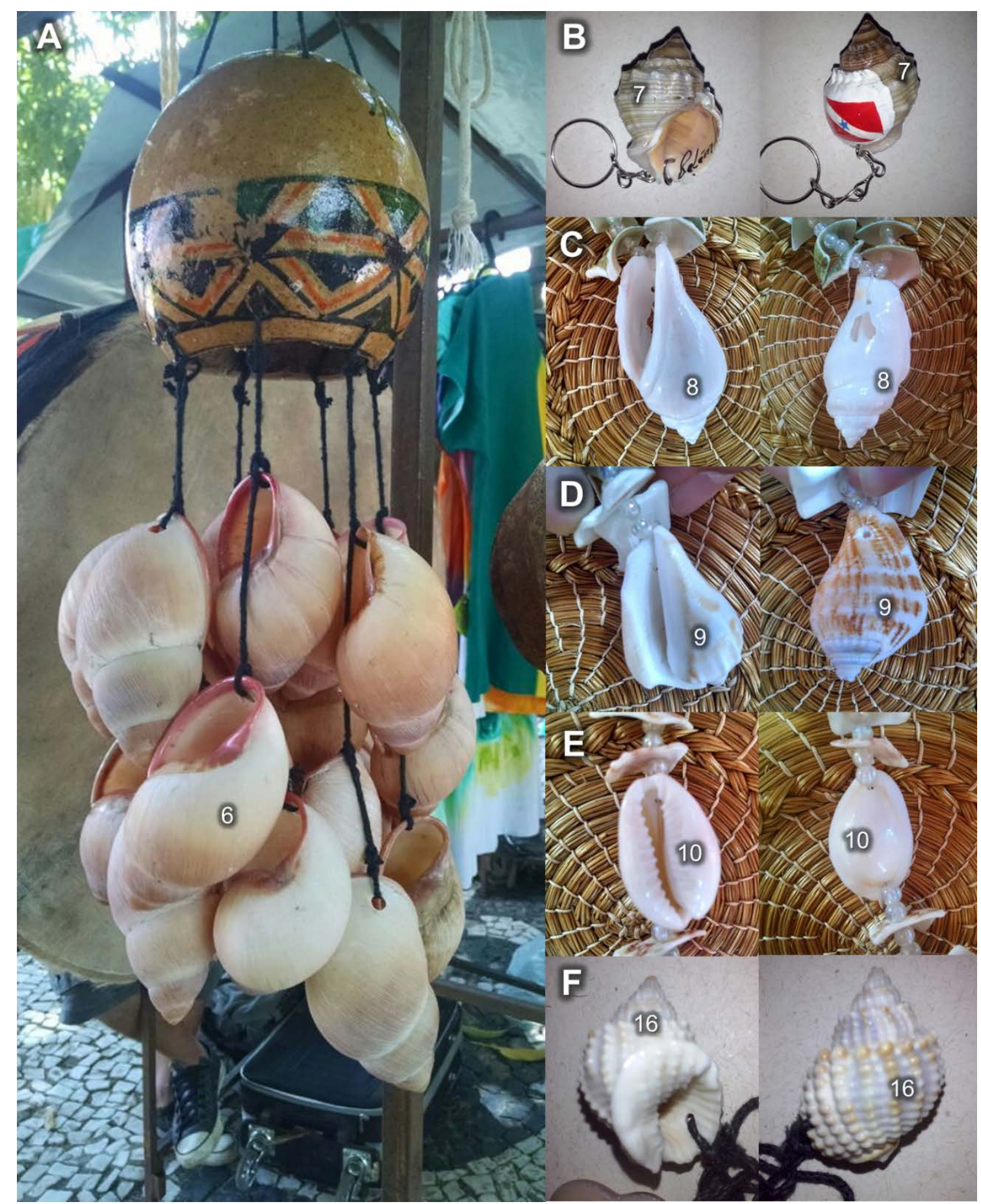

Figure 2. A to F are an example of zoohandicraft marketed in the Amazon Region. Species used: Megalobulimus leonardosi (6), Stramonita brasiliensis (7), Olivella sp. (8), Lobatus raninus (9), Naria acicularis (10), and Nassarius conoidalis (16). 


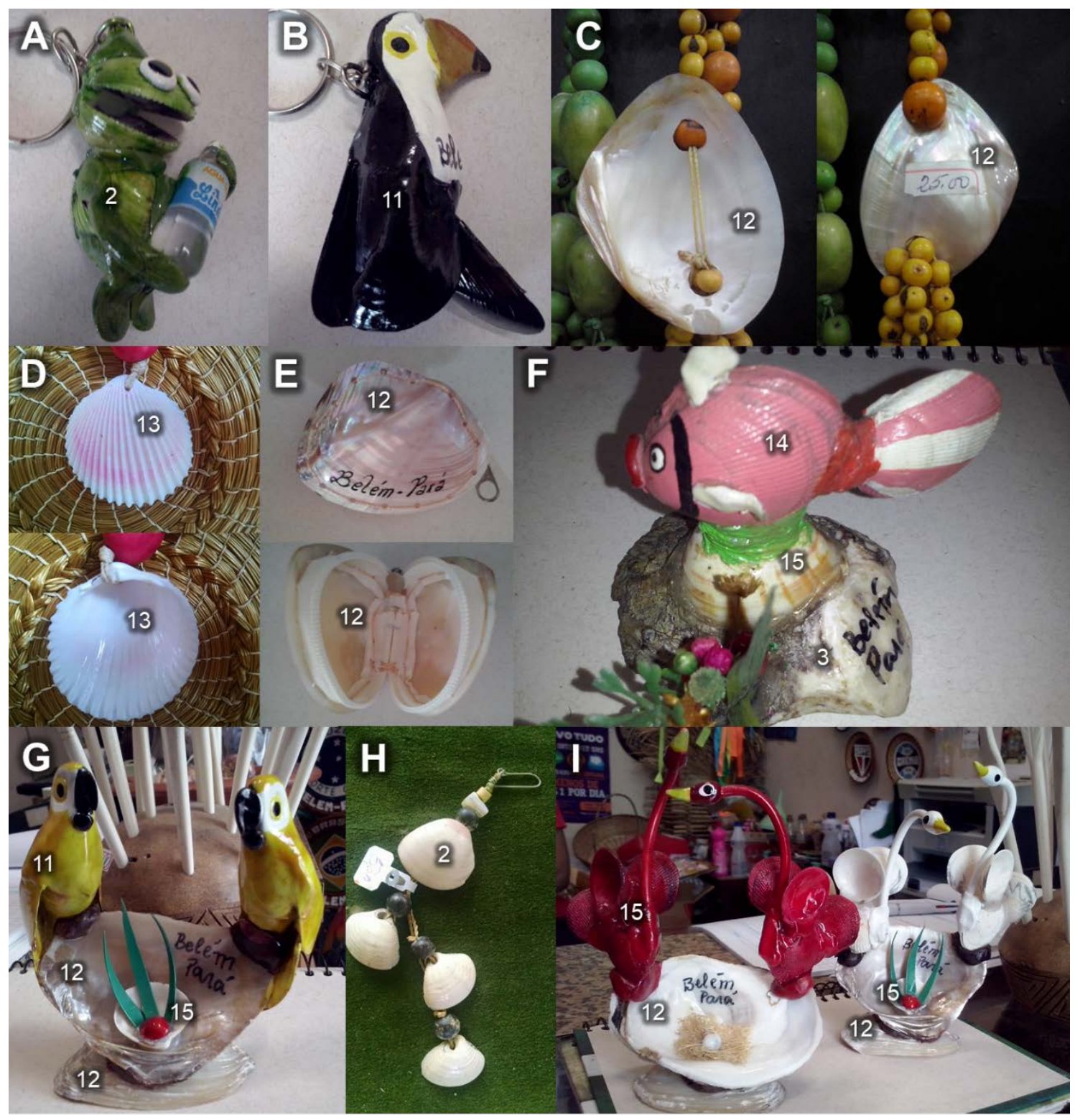

Figure 3. A to I are an example of zoohandicraft marketed in the Amazon region. Species used: Anomalocardia flexuosa (2), Mytella guyanensis (11), Triplodon corrugatus (12), Dallocardia manueli (13), Leukoma pectorina (14), and Tivela mactroides (15).

In this study, the results about Alves et al. (2006) and Silva et al. (2007), highlight the bivalve A. flexuosa (updated scientific name of $A$. brasiliana) among the greatest abundances in the zoohandicraft confection. However, the impact of fishing/utilization of this mollusk is not mentioned in studies related to the population dynamics of the species (Boehs et al., 2008; Rodrigues et al., 2010; Santos et al., 2014; Barros, 2017).

Tenório et al. (2002) cite that the mollusks are fished casually or by order to make the zoohandicraft. Alves et al. (2006) comment that gastropod mollusk shells are easily found in public places (e.g., open markets, open markets, and beaches) and that this practice is common in other regions of Brazil and in 
several countries. The additional materials, used in the confection of Amazonian zoohandicraft, are similar to those found by Alves et al. (2006). Additionally, Alves et al. (2009) comments that even with the legislation in force, there is no supervision by the competent bodies and the commercialization of handicrafts using animal raw materials is free and indiscriminate at all points of sale.

\section{Conclusion}

Through this work and the collection of bibliographical data an absence of data on the production and the commerce and zoohandicraft was verified and, therefore, it is impossible to measure the effects of the anthropogenic pressure on the organisms used for the making of the materials, being the use of animals in zoohandicraft increases in parallel with tourism, which leads to greater exploitation of the species involved.

\section{Conflict of interest}

Authors declare that they have no conflict of interests.

\section{References}

Alves, M. S.; Silva, M. A.; Melo Júnior, M.; Paranaguá, M. N.; Pinto, S. L. Zooartesanato comercializado em Recife, Pernambuco, Brasil. Revista Brasileira de Zoociências, v. 8, no. 2, p. 99-109, 2006.

Alves, M. S.; Silva, M. A.; Pinto, S. L. Perfil sócio-econômico dos atores envolvidos na produção e comercialização de zooartesanato em Recife, Pernambuco - Brasil. Revista Nordestina de Zoologia, v. 4, no. 1, p. 97 $104,2009$.

Barros, M. R. F. Variações temporais na estrutura e composição do macrozoobentos de uma zona estuarina na Baía do Caeté, Norte do Brasil. Belém: Universidade Federal Rural da Amazônia, 2017. (Monografia de Bacharelado em Engenharia de Pesca).
Boehs, G.; Absher, T. M.; Cruz-Kaled, A. C. Ecologia populacional de Anomalocardia brasiliana (Gmelin, 1791) (Bivalvia, Veneridae) na Baía de Paranaguá, Paraná, Brasil. Boletim do Instituto de Pesca, v. 34, no. 2, p. 259-270, 2008.

Chagas, R. A.; Barros, M. R. F.; Bezerra, A. M. Morfometria da concha do gastrópode invasor Melanoides tuberculata (Müller, 1774) (Gastropoda, Thiaridae). Acta of Fisheries and Aquatic Resources, v. 6, no. 1, p. 10-16, 2018a. https://doi.org/10.2312/ Actafish.2018.6.1.10-16

Chagas, R. A.; Barros, M. R. F.; Santos, W. C. R.; Herrmann, M. Composition of the biofouling community associated with oyster culture in an Amazon Estuary, Pará State, Northern Brazil. Revista de Biologia Marina y Oceanografia, v. 53, no. 1, p. 9-17, 2018 b. https://doi.org/10.4067/S0718-195720180 00100009

Chagas, R. A.; Herrmann, M. Indução a desova de Crassostrea rhizophorae (Guilding, 1828) (Bivalvia: Ostreidae) através de métodos físico-químicos em condições controladas. Acta of Fisheries and Aquatic Resources, v. 3, no. 2, p. 24-30, 2015. https://doi.org/ 10.2312/ActaFish.2015.3.2.24-30

Chagas, R. A.; Herrmann, M. Estimativas de crescimento de bivalves tropicais e subtropicais: recomendação para um método padronizado. Acta of Fisheries and Aquatic Resources, v. 4, no. 2, p. 28-38, 2016. https://doi.org/10.2312/ActaFish.4016.4.2.2 8-38

Farias, M. F.; Rocha-Barreira, C. A. Conchas de moluscos no artesanato cearense. Fortaleza: NAVE/LABOMAR-UFC, 2007.

Jesus, A. R. B.; Sousa, T. C. L.; Silva, R. E. O.; Freire, C. C. O.; Abreu, V. S.; Barros, M. R. F.; Chagas, R. A.; Herrmann, M. Moluscos utilizados no zooartesanato comercializado em Belém, Pará, Brasil. Proceeding of the XX Congresso Brasileiro de Engenharia de Pesca, Florianópolis, 2017.

Matthews-Cascon, H.; Barreira, C. A. R. Moluscos do litoral do Estado do Ceará. In: Matthews-Cascon, H.; Lotufo, T. M. Biota marinha da costa oeste do Ceará. Brasília: MMA, 2006. p. 113-144.

Rios, E. C. Compendium of Brazilian sea shells. Rio Grande: Evangraf, 2009. 
Rodrigues, A. M. L.; Borges-Azevedo, C. M.; Henry-Silva, G. G. Aspectos da biologia e ecologia do molusco bivalve Anomalocardia brasiliana (Gmelin, 1791) (Bivalvia, Veneridae). Revista Brasileira de Biociências, v. 8, no. 4, p. 377-383, 2010.

Santos, J. J. S.; Terceiro, A. M.; Yauri, W. L. M. Dinâmica da população de Anomalocardia brasiliana (Mollusca, Bivalvia, Veneridae) no Estuário do Rio Paciência, no Município da Raposa, Estado do Maranhão. Anuário do Instituto de Geociências - UFRJ, v. 37, no. 1, p. 61-69, 2014.

Silva, A. F.; Dias, T.; Costa, A.; Santos, R.; Bezerra, A. R. Zooartesanato comercializado na costa da Paraíba (Nordeste do Brasil): implicações ecológicas e conservacionistas. Proceeding of the VIII Congresso de Ecologia do Brasil, Caxambu, 2007.
Sousa, M. D. B.; Farias, L. C. F.; Barros, M. R. F.; Chagas, R. A.; Herrmann, M. Gastrópodes utilizados no zooartesanato do Município de Belém, Pará. Proceeding of the XII Seminário de Iniciação Científica da UFRA, Belém, 2014.

Subirá, R. J.; Galvão, A.; Carvalho, C. E. G. Livro vermelho da fauna brasileira ameaçada de extinção. Brasília: ICMBio/MMA, 2018. v. 1.

Tenório, D. O.; Luz, B. R. A.; Melo, W. R. Moluscos marinhos do litoral do Estado de Pernambuco. In: Tabarelli, M.; Silva, J. M. C. Diagnóstico da biodiversidade de Pernambuco. Recife: Secretaria de Ciência e Tecnologia e Meio Ambiente, Fundação Joaquim Nabuco, Ed. Massangana, 2002. p. 493-528. 